\title{
Total viable ruminal bacteria and volatile fatty acids in ruminants fed diets containing proteins of different degradabilities
}

\author{
S Puppo, F Martillotti, F Grandoni, S Terramoccia
}

\author{
Istituto Sperimentale per la Zootecnia, via Salaria 31, Monterotondo Sc, Rome, Italy
}

The influence of protein supplements of different rumen degradability (DT\%) on the ruminal microbial number in dairy cows was studied.

Two Friesian cows were fed the following diets: $A=100 \%$ Polyphyta hay; $B=10 \%$ extracted soybean meal (DT 70\%) + 90\% Polyphyta hay; $\mathrm{C}=10 \%$ corn gluten meal (DT $30 \%$ ) $+90 \%$ Polyphyta hay. The crude protein content was $8.2 \%$ for $\operatorname{diet} A, 12.7 \%$ for diets $B$ and $C$ respectively. The diets were given according to a factorial design with changeover. The animals were fed twice daily and samples of whole rumen contents were withdrawn $3 \mathrm{~h}$ after morning feeding for 2 consecutive $d$. The total microbial number was determined by direct count on Petri dishes in $\mathrm{BH}$ agar medium (Holdeman et al, 1977) under an anaerobic glove box (atm $95 \% \mathrm{CO}_{2} ; 5 \%$ $\mathrm{H}_{2}$ ) after $5 \mathrm{~d}$ incubation at $39^{\circ} \mathrm{C}$. The rumen volatile fatty acid levels (VFA) were determined by gas chromatography.

The total microbial counts were $1.23 \pm 0.75$ $\times 10^{10}, 0.59 \pm 0.40 \times 10^{10}$ and $0.83 \pm 0.30$ $\times 10^{10}$ cells/g dry rumen content for diets $A, B$ and $C$ respectively. Diet $A$ had slightly higher $(P \leq 0.25)$ microbial counts compared to diet B. No difference was found between diet $A$ and $\mathrm{C}$ or between $\operatorname{diet} \mathrm{B}$ and $C$. The data showed high SD values owing to variability between animals.

Acetic, propionic and butyric acid content of diet A was found to be significantly higher compared to diet B. No significant difference was found between $C$ and the other 2 diets.

In conclusion, supplementation by protein with faster rumen degradability kinetics compared to Polyphyta hay and corn gluten feed negatively affected the production of ruminal microflora and consequently the VFA content decreased, probably since the $\mathrm{N}$ and $\mathrm{C}$ sources of the diet were not available at the same time for microbial growth (Wallace et al, 1988).

Holdeman LV, Cato EP, Moore WEC (1977) Anaerobe Laboratory Manual. Virginia Polytech Inst and State Univ, VA, 4 th edn, 1-156

Wallace RJ, Cotta MA (1988) The rumen Microbial Ecosystem (Hobson PN, ed) Elsevier Appl Sci, Amsterdam, 217-227

Table I. Volatile fatty acid data $(\mathrm{mmol} / 100 \mathrm{ml}$ rumen fluid).

\begin{tabular}{llll}
\hline Diet & Hay & Soy & Corn gluten \\
\hline Acetic acid & $2.26 \pm 1.57^{\mathrm{A}}$ & $1.44 \pm 0.38 \mathrm{~B}$ & $1.91 \pm 1.59^{\mathrm{AB}}$ \\
Propionic acid & $0.90 \pm 0.10^{\mathrm{a}}$ & $0.53 \pm 0.17^{\mathrm{b}}$ & $0.68 \pm 0.49^{\mathrm{ab}}$ \\
Isobutyric acid & $0.05 \pm 0.01$ & $0.09 \pm 0.03$ & $0.12 \pm 0.07$ \\
Butyric acid & $0.61 \pm 0.04^{\mathrm{a}}$ & $0.39 \pm 0.12^{\mathrm{b}}$ & $0.44 \pm 0.33^{\mathrm{ab}}$ \\
\hline
\end{tabular}

A,B $P \leq 0.05 ;$ a,b $P \leq 0.10$. 